\title{
REIT-Specific and Macroeconomic Determinants of REIT Returns: Evidence from Singapore
}

\author{
Parvinder Arora ${ }^{1}$, Robert Killins ${ }^{1} \&$ Prameela Gangineni ${ }^{2}$ \\ ${ }^{1}$ Professor, School of Accounting and Financial Services, Seneca College, Toronto, Canada \\ ${ }^{2}$ Freelance Researcher, Singapore \\ Correspondence: Parvinder Arora, Professor, School of Accounting and Financial Services, Seneca College, Toronto, \\ Canada. E-mail: parvidner.arora@senecacollege.ca
}

Received: April 14, 2019

Accepted: June 6, 2019

Online Published: June 27, 2019

doi:10.5430/afr.v8n3p27

URL: https://doi.org/10.5430/afr.v8n3p27

\begin{abstract}
We examine the determinants of REIT returns in a highly developed trade-oriented market economy - Singapore. For the period from 2004 to 2013, we conduct panel data analyses on the impacts of REIT characteristics and macroeconomic factors on the returns of Singapore Real Estate Investment Trusts (S-REITs). Our results indicate that the returns of S-REITs are affected by the book-to-market value but not earnings per share, the debt-to-equity ratio, or the dividend yield. From the macroeconomic perspective, both local and international economic conditions, including the gross domestic product, inflation rate, exchange rate, and money supply are significantly related to the returns of S-REITs, indicating that the market of S-REITs is an imperfectly integrated one.
\end{abstract}

Keywords: Singapore real estate investment trusts (S-REITs), REIT characteristics, macroeconomic factors

JEL Classification Numbers: G11, G12, G15

\section{Introduction}

Real Estate Investment Trusts (REITs) are high asset-based stocks where the income is generated mainly from leasing properties. REITs are traded in stock markets just like other stocks, and they attract investors through their high dividend payments. Titman and Warga (1986), and Ling and Naranjo (2015) analyzed the performance of REITs using the CAPM approach and found that REITs are more volatile, but highly transparent compared to other equity assets. Moreover, numerous studies were performed on the U.S. REITs, focusing on the capital structure, market performance, the role of REITs in a mixed-asset portfolio, and dividend policies (Basse et al. 2009; Chang et al. 2011; Su et al. 2010; Zietz et al. 2003;). Further, a substantial amount of research had been performed to determine the correlation among REITs, bonds, real estate properties, and other equity stocks (Clayton and MacKinnon, 2003; Fei et al. 2010; Hardin III and Hill 2008; Li and Lei 2011;). In short, the performance of REITs are found to be similar to traditional real estate properties in the long term (Han and Liang, 2009) and value equity stocks in the short term (Quan and Titman, 1999).

In Singapore, the Monetary Authority of Singapore launched the first REIT in July 2002. The market of Singapore REITs (S-REITs) has since grown to $\$ 56$ billion in size and is now listed as the $30^{\text {th }}$ largest asset class on the Singapore stock exchange. Similar to U.S. REITs, S-REITs distribute a minimum of 90 percent of their earned incomes in the form of dividends to their shareholders. Although several studies (e.g., Fei et al., 2010 and Lizieri et al., 2009) have been conducted on the U.S. REITs to determine their performance and behavior, there is little evidence of studies that have been conducted to determine the REIT-specific and macroeconomic factors that influence the price of S-REITs. Therefore, the purpose of this paper is to examine the REIT-specific and macroeconomic factors that explain the price of S-REITs.

The structure of the paper is as follows. Section 2 reviews prior studies and develops hypotheses. Section 3 describes the data and methodology. Section 4 provides the findings of this paper. Finally, Section 5 provides the conclusion and presents the limitation of this paper.

\section{Literature Review}

REITs (Real Estate Investment Trust) is a corporation (or) trust (or) organization created for holding real estate properties and mortgage assets. REITs were formally formed in 1960 in the US and had undergone many structural 
changes to attract small investors. REITs are considered to have a high liquid asset compared to the real estate market, and it is a growing force in the emerging markets and is becoming an investment vehicle for the small-scale investors in order to expose them to the real estate market (Ang et al., 2013; Elliott and Timmermann, 2013).

From a micro level perspective, the Fama and French (1988) study on non-REIT firms indicates a positive correlation between book-to-market value and share return in non-REITs firms. Brounen and de Koning (2013) show that REITs market beta has a significantly positive relationship with the market factor. Saeidi and Khandoozi (2011) found that the earning per share is an important factor when explaining returns, along with dividend payout and the $\mathrm{P} / \mathrm{E}$ ratio. Additionally, Kim (1997) found that beta has significant explanatory power on stock returns, regardless of the inclusion of other factors such as book-to-market and firm size. Chen et al. (1998) found that the market beta was not significant when firm, market, and the macroeconomic variables were included in the model. This indicates that the CAPM model has less explanatory power to explain the variations in the share returns based on the market beta.

The Arbitrage Pricing Theory created by Ross (1976) provides an alternative to the CAPM theory where it estimated the riskiness of the asset return and showed that it could be determined by the risk premium of macroeconomic factors. Chen et al. (1986) showed that stock returns are significantly related to macroeconomic factors like industrial production index, changes in the market indices, change in interest rates, and inflation rate. In contrast, Chen et al. (1998) found that the market beta was not significant when the firm, market, and macroeconomic variables were included in the model. This indicates that the CAPM model has less explanatory power to explain the variations in the share returns based on the market beta. Payne (2003) extended the study of Chen et al. (1986) to REITs and showed a significant negative correlation between REITs stock return and the growth of industry and term spread. A negative correlation was observed between book-to-market and REITs returns, but this result did not show any explanatory power with stock returns, which is inconsistent with (Su et al. 2010).

REITs excess returns can predict the GDP growth rate at least two quarters in advance (Li and Lei 2011) while Fei et al. (2010) found that macroeconomic factors such as the term spread, unemployment rate and inflation rate effect REIT returns. Furthermore, Nelling and Gyourko (2009) who study on the predictability of REITs with the historical prices, identified that the predictability of REITs is low compared to equity returns. However, it has been documented that the behavior of REITs is similar to the small-cap equities (e.g., Liow and Li, 2006).

In summary, numerous studies had been conducted to determine the performance of the share price using the following three factors - firm fundamental, macroeconomic, and market proxy. Additionally, many researchers have performed research to determine REIT returns on market proxy using CAPM in the U.S and Europe. It was found that the market beta has a significant correlation with share returns, but it loses its explanatory power when micro and macro determinants are included. Furthermore, REITs performance in a mixed-asset portfolio can be affected by the macroeconomic factors like GDP, interest rates, house price index, and inflation rates, while non-real estate stock prices are affected by the fundamental factors like earning price ratios, dividends, net asset values, and firm size. However, there is little research on the impacts of REIT specific, and macroeconomic factors on REIT returns in the Asian market. Thus, this paper focuses on discovering the relationship between REIT returns, REIT-specific, and macroeconomic variables using panel data analysis with data from the Singapore market.

\subsection{Hypotheses Development}

Table 1 provides a summary of the hypotheses in this study. Below we will expand on both REIT-specific and macroeconomic variables, and the expected impacts on Singapore REIT returns.

\subsubsection{REIT-Specific Variables}

Earnings per share: Earnings per share (EPS) represents the company's overall profitability. Brown (1978) found that earnings per share play a significant role in stock returns. However, the effects of the earnings announcements will not be immediate. Rather, it will affect stock returns in the long run. According to Chang et al. (2008), earnings per share has a significant correlation with market returns in the long run. Thus, this study predicts that the earnings per share are a significant positive factor that explains REIT returns in Singapore.

\section{$H_{1}$ - Earning per share has a positive impact on Singapore REIT returns}

Book-to-market value: Book-to-market value (BTM) represents the safety of the shareholders' investment after accounting for the book value of capital in the company. The existing literature is mixed when trying to determine the effect of the book-to-market on share return. A high ratio is preferred by value managers who interpret it to mean that the company is a value stock. That is, it is trading cheaply in the market compared to its book value. We 
suggest the investors prefer value REIT when investing in the real estate asset class and thus expect a positive relationship between the book-to-market and REIT returns.

$H_{1}$ - Book-to-market value has a positive relationship with Singapore REIT returns

Dividend Yield: According to Fama and French (1988), dividend yields were used to forecast the returns, and a high correlation was found in expected returns of the share prices (Yung et al. 2017). Sah and Zhou (2012) examined the reaction of the REITs returns and the announcements of the dividends and found an abnormal increase in the REITs shares turnover after the dividend announcements. Thus, this study expects to find a positive relationship between the dividend yield and REIT returns.

\section{$H_{1}$ - Dividend yield has a positive relationship with Singapore REIT returns}

Total Debt-to-Equity: The debt-to-equity ratio documents the company's capital structure. Bhandari (1988) study found that the debt-to-equity ratio has a significant positive correlation with equity returns. Spiess and Affleck-Graves (1999) found strong evidence of underperformance with debt offerings. However, markets tend to under-react at the time of the debt offerings. Hence, the full impact will only be noticed in long-run. Therefore, we predict that highly levered REITs will underperform less leveraged REITs.

$H_{1}$ - There is a negative relationship between debt-to-equity ratio and Singapore REIT returns

\subsubsection{Macro Variables}

GDP: Gross Domestic Production (GDP) represents the value of the goods and services produced every year by a country. Quan and Titman (1999) found that real estate prices are significantly influenced by GDP growth rates. Therefore, we expect that GDP growth will have a positive influence on Singaporean REIT returns.

\section{$H_{1}$ - Positive relationship between GDP and S-REIT returns}

Inflation rate: Inflation rate measures the rise in the level of the prices of goods and services in a country. Inflation rate affects the revenue and capital structure decisions within the firm. In this study, we predict the inflation rate will affect the share price negatively.

\section{$H_{1}$ - Negative relationship between inflation rate and S-REIT returns}

Term/Yield structure of interest rates: The interest rate is the rate at which companies can borrow the money from the bank in short/long time period to fulfill short-term needs for investments. The value of stocks is discounted by the interest rates. A previous study by Rjoub et al. (2009) determined the term structure as the difference between the long-term government bond and the short-term government bond, while Payne (2003) defined the term structure as the difference between a 10-year government bond and 3-month treasury bill. The term structure can have varying impacts on expected returns depending on the short/long term capital structure of the firm. Since most REIT firms have a capital structure with significant long-term debt, we expect that increases in the yield curve will result in higher borrowing costs and have a negative impact on REIT returns.

$H_{1}$ - There is a negative relationship between the yield curve and S-REIT returns

Money Supply: Money supply determines the stock of money/currency available to be circulated in the country. The sudden increase in the money supply will increase the inflation rate. Money supply and the monetary policies revolved in controlling the interest rates and money flow into the economy. M1 is defined as the demand of currency available for private circulation, and M2 is the M1plus deposits in banks. Rogalski and Vinso (1977) study on stock returns and money supply used M1 to determine the causality. This study used M1 to determine the relationship between the money supply and share price, and we expect a positive relationship between money supply (M1) and Singapore REIT returns.

\section{$H_{1}$ - Positive correlation between money supply and S-REIT returns}

Exchange Rate: The exchange rate is the rate at which one currency will be exchanged to another. Singapore benefits from foreign investments, as the Singapore REITs are well diversified geographically. Granger et al. (2000) found that the exchange rate is negatively related to stock return. Hence, the exchange rate may play a significant role in the returns of Singapore REITs. We expect the as the Singapore currency falls in value, more investment will be generated in Singapore and thus have a positive impact on Singapore REITs.

$H_{1}$ - Negative relationship between the exchange rates and $S$-REIT returns 


\section{Research Methodology}

\subsection{Data Collection}

Quarterly data from 2004 to 2013 for S-REITs and macroeconomic factors were collected from various sources, as shown in Table 2. Data were collected from 23 REITs companies listed on the Singapore Stock Exchange and a list is provided in Table 3. The variables in the panel data set are as follows. SR is defined as the share return or percentage of the difference between the REIT price at time $t$ and $t-1$. Explanatory variables include earning-per-share (EPS), Book-to-market value (BTM), and debt-to-equity ratio (DE) and dividend yield (DY).

Table 1. Summary of Hypotheses and Related Literature

\begin{tabular}{|c|c|}
\hline Hypothesis & Related Literature \\
\hline $\begin{array}{l}\text { 1. Earning per share has no impact on Singapore } \\
\text { REIT returns }\end{array}$ & Chang et al. (2008) \\
\hline $\begin{array}{l}\text { 2. Book-to-market value has a positive relationship } \\
\text { with Singapore REIT returns }\end{array}$ & $\begin{array}{l}\text { Chui et al. (2003) } \\
\text { Peterson and Hsieh (1997) }\end{array}$ \\
\hline $\begin{array}{l}3 . \\
\text { Yield has a positive impact on Singapore REIT returns }\end{array}$ & Sah and Zhou (2012) \\
\hline $\begin{array}{l}4 . \quad \text { There is a } \\
\text { negative relationship between debt-to-equity ratio and } \\
\text { Singapore REIT returns }\end{array}$ & Spiess and Affleck-Graves (1999) \\
\hline $\begin{array}{l}5 . \\
\text { positive relationship between GDP and REIT returns }\end{array}$ & Quan and Titman (1999) \\
\hline $\begin{array}{l}6 . \\
\text { negative relationship between inflation and Singapore } \\
\text { REIT return }\end{array}$ & Lu and So (2001) \\
\hline $\begin{array}{l}7 . \\
\text { negative relationship between interest rates and } \\
\text { Singapore REIT returns }\end{array}$ & $\begin{array}{l}\text { Chang et al. (2011) } \\
\text { Chen et al. (1998) }\end{array}$ \\
\hline $\begin{array}{l}\text { 8. There is a positive relationship between money } \\
\text { supply and Singapore REIT returns }\end{array}$ & $\begin{array}{l}\text { Chang et al. (2011) } \\
\text { Chen et al. (1998) }\end{array}$ \\
\hline $\begin{array}{l}\text { 9. There is a negative relationship between } \\
\text { exchange rates and Singapore REIT returns }\end{array}$ & Liu and Mie (1998) \\
\hline
\end{tabular}

Table 2. Data Collection

\begin{tabular}{ll}
\hline Name & Source \\
\hline GDP & Capital IQ \\
Inflation Rate & MAS \\
Money Supply & MAS \\
Term Structure & MAS \\
Exchange Rate & MAS \\
REITs firm variables & Bloomberg \\
\hline
\end{tabular}


Table 3. Singapore REITs

\begin{tabular}{ll}
\hline Name & Code \\
\hline Frasers Comm & ND8U \\
Ascendasreit & A17U \\
AscottREIT & A68U \\
Cambridge & J91U \\
CapitaComm & C61U \\
CapitaMall & C38U \\
CapitaRChina & AU8U \\
CDL HTrust & J85 \\
First REIT & AW9U \\
Fortune Reit HK\$ $\$$ & \\
FrasersCT & J69U \\
LippoMalls & D5IU \\
Kep REIT & K71U \\
AIMSAMPI Reit & O5RU \\
MapletreeLog & M44U \\
Starhill Gbl & P40U \\
PLife REIT & C2PU \\
SuntecReit & T82U \\
MapletreeCom & N2IU \\
CACHE & K2LU \\
MapletreeInd & ME8U \\
Sabana REIT & M1GU \\
\hline
\end{tabular}

\subsection{Empirical Methodology}

This study used both firm and macroeconomic variables to analyze the impact on the share returns of S-REITs. The relation between the stock prices and the firm and macroeconomic variables can be explained with the following regression equation;

$$
\frac{\Delta S P_{\mathrm{t}}}{S P_{t-1}}=\alpha+\sum_{i=1}^{\mathrm{n}} \beta_{\mathrm{it}} * M A C R O_{i t}+\sum_{i=1}^{\mathrm{n}} \theta_{\mathrm{it}} * F_{I R M_{i t}}+\varepsilon_{t}
$$

where $\frac{\Delta S P_{\mathrm{t}}}{S P_{t-1}}$ represents the percentage of share return from previous time period. Alpha $(\alpha)$ is the constant variable; macro term represents all the macro economic variables (GDP, inflation rate, interest rate and money supply). Firm term represents the firm variables - EPS, BTM, DE and DY. Beta $(\beta) \& \theta$ represent the positive (or) negative coefficients restrictions placed to explain the relation of the independent variable and the dependent variable.

\subsubsection{Panel Data Analysis}

Panel data analysis is estimated using pooled OLS model, fixed effect model, and random effects model. To identify the efficient model, we conduct (i) F-tests to compares the fixed effect model and pooled OLS in order to determine the goodness of fit, (ii) Breusch-Pagan LM Test to decide whether to fit between the random effect model and OLS regression model, and (iii) Hausman test to evaluate the goodness of fit between the fixed effect and random effect models. 


\section{Empirical Analysis \& Results}

\subsection{Descriptive Statistics}

Table 4 represents the summary of statistics for nine years of quarterly data collected from 23 REITs companies listed in Singapore Stock Exchange and the Singapore macroeconomic variables. The results in Table 5 show the correlation matrix of all the explanatory variables used in this study. As a rule of thumb, higher correlation (greater than $80 \%$ ) between two variables may raise multicollinearity errors, which lead to high standard errors in the regression results. We do not observe significant issues of multicollinearity in the data.

Table 4. Descriptive Statistics of Share Return and independent variables

\begin{tabular}{|c|c|c|c|c|c|c|c|c|c|}
\hline & Observation & Mean & St.D & Median & Min & Max & Range & Skew & Kurtosis \\
\hline \multicolumn{10}{|c|}{ Dependent Variable } \\
\hline SR & 562 & 0.02295 & 0.20 & 0.02000 & -0.72 & 0.73000 & 0.17193 & 0.12019 & 2.6883 \\
\hline \multicolumn{10}{|c|}{ Independent variables } \\
\hline \multicolumn{10}{|c|}{ Firm Variables } \\
\hline EPS & 583 & 0.03 & 0.11 & 0.02 & -0.51 & 1.21 & 1.72 & 3.58 & 39.08 \\
\hline BTM & 578 & 1.32 & 0.78 & 1.31 & 0.32 & 7.92 & 7.60 & 3.42 & 18.59 \\
\hline $\mathrm{DE}$ & 579 & 0.51 & 0.21 & 0.48 & 0 & 1.58 & 1.58 & 1.97 & 3.80 \\
\hline DY & 436 & 7.77 & 4.37 & 6.66 & 0.02 & 39.21 & 39.19 & 3.37 & 16.93 \\
\hline \multicolumn{10}{|c|}{ Macro Variables } \\
\hline GDPN & 851 & 0.08 & 0.07 & 0.1 & -0.08 & 0.2 & 0.28 & -0.47 & -0.27 \\
\hline INF & 851 & 2.12 & 1.57 & 1.9 & -1.4 & 6.5 & 7.9 & 0.66 & 1.39 \\
\hline TR & 851 & 1.43 & 0.77 & 1.36 & -0.05 & 3.08 & 3.13 & 0.11 & -0.63 \\
\hline $\mathrm{EX}$ & 851 & 1.45 & 0.16 & 1.44 & 1.22 & 1.72 & 0.5 & 0.12 & -1.28 \\
\hline MS & 851 & 82340.35 & 34347.41 & 75633.7 & 41118.9 & 148864.4 & 107745.5 & 0.4 & -1.27 \\
\hline
\end{tabular}

Note: This is a correlation matrix based on the 23 Singapore REITs firms and the macroeconomic variables. Firm variables: Book-to-market ratio (BTM), Debt-to-Equity (DE), Dividend Yield (DY) and earning per share (EPS). Macroeconomic variables: GDPN represents Nominal Gross Domestic Product, EX is the exchange rate between Singapore dollar and US dollar, Term Structure (TS) is the difference between 10-year Singapore government bond and 3-month Singapore T-bill, MS is the M1 money supply of Singapore and INF is Singapore inflation rate

Table 5. Correlation Matrix

\begin{tabular}{llllllllll}
\hline & DE & DY & BTM & EPS & EX & TS & MS & IF & GDPN \\
\hline DE & 1.0000 & & & & & & & & \\
DY & 0.184509 & 1.0000 & & & & & & & \\
BTM & 0.122875 & 0.780246 & 1.0000 & & & & & \\
EPS & -0.248557 & -0.46606 & -0.37695 & 1.0000 & & & & \\
EX & 0.02786 & 0.217687 & 0.275014 & -0.06029 & 1.0000 & & & \\
TS & $4.22 \mathrm{E}-05$ & 0.230024 & 0.171555 & -0.16413 & -0.20815 & 1.0000 & & \\
MS & -0.048047 & -0.13084 & -0.2139 & 0.008934 & -0.90268 & 0.1088 & 1.0000 & & \\
INF & 0.091721 & -0.01096 & 0.115328 & 0.081228 & -0.0644 & -0.08386 & -0.19417 & 1.0000 & \\
GDPN & -0.107127 & -0.44316 & -0.4846 & 0.26567 & 0.15207 & -0.04268 & -0.21494 & -0.20773 & 1.0000
\end{tabular}

Note: This is a correlation matrix based on the 23 Singapore REITs firms listed and the Macroeconomic variables. Firm Variables: Book-to-market ratio (BTM), Debt-to-Equity (DE), Dividend Yield (DY) is ratio of dividends relative to share price and Earning per share. Macroeconomic variables, GDPN represents Nominal Gross Domestic Product, EX is the exchange rate between Singapore dollar and US dollar, Term Structure (TS) is the difference between 10 year Singapore government bond and 3 month Singapore T-bill to represent the interest rates, MS is the M1 money supply of Singapore, INF is Singapore Inflation rate 


\subsection{Data Results and Analysis}

The panel data collected for this study was estimated using pooled OLS, fixed effect, and random effect techniques. The Hausman test was used to compare both fixed and random models and to test the efficiency of the random effects, and the null hypothesis is in favor to the random effects and considered random model is consistent and efficient. A series of tests were conducted to estimate the efficient technique, BP-LM test results in Table 6 are significant to reject the null hypothesis, these results are in favor of individual and (or) time effects in all the models. The Hausman test results showed single regression models (Models 1 to 4 ) in Table 5 are in favor of the random effects, and firm variable model (FVM - model 5) is in favor to the fixed effect. Table 6 provides the result of most efficient panel model for single regression models and firm variable model (FVM) as explained in equation (1), while the serial correlation and heteroskedasticity errors in the model provided inefficient results. Because of this, the Breusch-Godfrey serial correlation test was used to test the serial correlation in panel data models and Breush-Pagan for heteroskedasticity test. Robustness against serial correlation and heteroskedasticity using the Arellano method was also used in this study to correct serial correlation and heteroskedasticity in panel models (Croissant and Millo, 2008).

Table 6. Firm Variables Regression Results

\begin{tabular}{|c|c|c|c|c|c|}
\hline & Model-1(c) & Model-2(c) & Model-3(c) & Model-4(c) & Model-5(b) \\
\hline Intercept & $\begin{array}{l}0.029159 \\
(1.2972) \\
{[0.1951]}\end{array}$ & $\begin{array}{l}0.1127139 \\
(4.8095) \\
{[1.95 \mathrm{e}-06]^{* * *}}\end{array}$ & $\begin{array}{l}0.057536 \\
(2.3070) \\
{[0.02142]^{*}}\end{array}$ & $\begin{array}{l}0.0608433 \\
(2.1055) \\
{[0.03583]^{*}}\end{array}$ & \\
\hline EPS & $\begin{array}{l}-0.010389 \\
(-0.2075) \\
{[0.8357]}\end{array}$ & & & & $\begin{array}{l}-0.2613285 \\
(-2.8018) \\
{[0.005324]^{*}}\end{array}$ \\
\hline BTM & & $\begin{array}{l}-0.0659275 \\
(-8.8532) \\
{[<2.2 \mathrm{e}-16]^{* * *}}\end{array}$ & & & $\begin{array}{l}-0.1316028 \\
(-5.1552) \\
{[0.0000003954]^{* * *}}\end{array}$ \\
\hline DE & & & $\begin{array}{l}-0.058704 \\
(-2.4849) \\
{[0.01325]^{*}}\end{array}$ & & $\begin{array}{l}-0.0618308 \\
(-0.9637) \\
{[0.335773]}\end{array}$ \\
\hline DY & & & & $\begin{array}{l}-0.0060142 \\
(-4.0575) \\
{[5.883 \mathrm{e}-05]^{* * *}}\end{array}$ & $\begin{array}{l}0.0036338 \\
(-0.8594) \\
{[0.390642]}\end{array}$ \\
\hline $\mathrm{R}$ - Squared & 0.0014208 & 0.12385 & 0.011821 & 0.03665 & 0.14624 \\
\hline $\begin{array}{l}\text { Adjst - R Squared } \\
\text { F-statistics }\end{array}$ & $\begin{array}{l}0.0014157 \\
0.480589\end{array}$ & $\begin{array}{l}0.12341 \\
78.8721 * * *\end{array}$ & $\begin{array}{l}0.011779 \\
6.64775^{*}\end{array}$ & $\begin{array}{l}0.036482 \\
16.5086^{* * * *}\end{array}$ & $\begin{array}{l}0.1375 \\
17.5148 * * *\end{array}$ \\
\hline $\begin{array}{l}\text { (BP-LM test) } \\
\text { Hausman Test }\end{array}$ & $\begin{array}{l}2.2 \mathrm{e}-16 \\
0.7937\end{array}$ & $\begin{array}{l}<2.2 \mathrm{e}-16 \\
0.7716\end{array}$ & $\begin{array}{l}<2.2 \mathrm{e}-16 \\
0.7597\end{array}$ & $\begin{array}{l}<2.2 \mathrm{e}-16 \\
0.5401\end{array}$ & $\begin{array}{l}<2.2 \mathrm{e}-16 \\
1.301 \mathrm{e}-08^{* * *}\end{array}$ \\
\hline \multicolumn{6}{|c|}{ Serial Correlation \& Heteroskedasticity Test } \\
\hline $\begin{array}{l}\text { Serial Correlation } \\
\text { test (ChiSquare) }\end{array}$ & $\begin{array}{l}10.438 \\
{[0.165]}\end{array}$ & $\begin{array}{l}5.5119 \\
{[0.5977]}\end{array}$ & $\begin{array}{l}10.9183 \\
{[0.1422]}\end{array}$ & $\begin{array}{l}2.0236 \\
{[0.3636]}\end{array}$ & $\begin{array}{l}29.1036 \\
{[4.789 \mathrm{e}-07] * * *}\end{array}$ \\
\hline $\begin{array}{l}\text { Heteroskedasticity } \\
\text { test (B-P Value) }\end{array}$ & $\begin{array}{l}23.5292 \\
{[1.23 \mathrm{e}-06]}\end{array}$ & $\begin{array}{l}40.0006 \\
{[2.539 \mathrm{e}-10] * * *}\end{array}$ & $\begin{array}{l}12.2173 \\
{[0.00047]^{* * *}}\end{array}$ & $\begin{array}{l}35.6426 \\
{[2.37 \mathrm{e}-09] * * *}\end{array}$ & $\begin{array}{l}40.4258 \\
{[3.534 \mathrm{e}-08]^{* * *}}\end{array}$ \\
\hline
\end{tabular}

Note: See table 4 for variable descriptions. $\mathrm{BP}$ - LM test represents the Breush-Pagan Lagrange Multiplier test

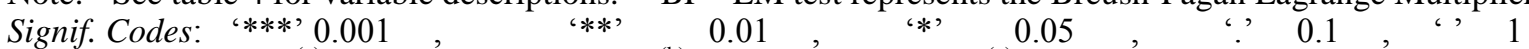
Model Estimation :- ${ }^{(a)}$ - Pooling Effect Model ${ }^{(b)}$ - Fixed Effect Model ${ }^{\left({ }^{(c)}\right.}$ - Random Effect Model Value in closed brackets are t-statistics and in Squared brackets are P-Value 


\subsubsection{REIT-specific factor results}

The firm variables include earning per share, book-to-market value, debt-to-equity ratio, and dividend yield measures the healthy growth of the firm and raised hope on returns for shareholder investment. Firstly, the single regression model observed the variations of stock return based on the selected firm variable. Secondly, the firm variable model considers all the firm variables as explanatory variables as per the equation - and finally, the combined model which includes both firm and macroeconomic factors used in the regression to estimate the correlation with the stock EPS is an essential measure of the performance of the investment. The estimation of EPS is interpreted as a profitability factor in single regression models (model 1 in Table 6). However, the results are not significant in the robust estimation model (model 1 in Table 7). Algebraically, the higher R-square with significant F-statistic at 0.05 showed better variance in explaining the dependent variable. Following the rule of thumb, R-square which represents the variance of the share return based on the explanatory variables in model 1 (Table 6) was less than $0.2 \%$, and the value of the F-statistic is not significant (0.49). Statistically, this model considered as inefficient. The FVM model estimates the relationship between selected firm variables and the stock return of Singapore REITs. The results did not show any significance at the 95\% level in robust estimation results (model-5 in Table 7). The combined model (Table 10) showed a negative correlation between earnings per share and share return.

Table 7. Robust Estimator Results

\begin{tabular}{|c|c|c|c|c|c|}
\hline & Model-1 ${ }^{(\mathrm{c})}$ & Model-2 $2^{(\mathbf{c})}$ & Model-3 $3^{(\mathrm{c})}$ & Model-4 $4^{(\mathrm{c})}$ & Model-5 $5^{(\mathbf{b})}$ \\
\hline \multirow[t]{3}{*}{ Intercept } & 0.029159 & 0.112714 & 0.057536 & 0.0608433 & \\
\hline & $(1.3213)$ & $(3.4671)$ & $(2.3388)$ & (1.8839) & \\
\hline & [0.1869] & {$[0.0005667]^{* * *}$} & {$[0.0197]^{*}$} & {$[0.06025]$.} & \\
\hline \multirow[t]{3}{*}{ EPS } & -0.010389 & & & & -0.2613285 \\
\hline & $(-0.1322)$ & & & & $(-1.3870)$ \\
\hline & [0.8949] & & & & [0.166194] \\
\hline \multirow[t]{3}{*}{ BTM } & & -0.065927 & & & -0.1316028 \\
\hline & & $(-2.5704)$ & & & $(-3.0922)$ \\
\hline & & {$[0.0104177]^{* * *}$} & & & {$[0.002123]^{* *}$} \\
\hline \multirow[t]{3}{*}{$\mathrm{DE}$} & & & -0.058704 & & -0.0618308 \\
\hline & & & $(-1.5436)$ & & $(-0.7108)$ \\
\hline & & & [0.1233 ] & & [0.477602] \\
\hline \multirow[t]{3}{*}{ DY } & & & & -0.0060142 & 0.0036338 \\
\hline & & & & $(-2.1650)$ & $(0.4103)$ \\
\hline & & & & {$[0.03093]^{*}$} & [0.681764] \\
\hline
\end{tabular}

Note: See table 4 for variable description. Table 6 provides description of statistical tests.

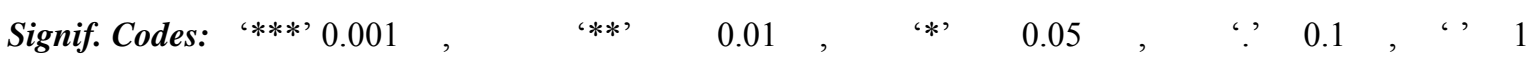

Model Estimation :- a - OLS Effect Model b- Fixed Effect Model c - Random Effect Model

Overall, all three models show that EPS reveal a negative effect on REIT returns. However, it did not show any significance in the single regression model or the FVM model. These results contradict with previous studies conducted by Chang et al. (2008) and Brown (1978) where EPS were correlated positively with the stock return in non-REITs firms. The findings are also not in line with (Foo Sing et al. 2002) who find that the property stock market EPS plays a significant role in both long term and short term. Thus, our results fail to provide support to our hypothesis that EPS will have a positive impact on S-REIT returns. This suggests that S-REIT investors may already 
anticipate positive earnings growth and that the REIT market in Singapore reacts differently compared to other well developed REIT markets.

REITs are massive asset-based firms and formed from the real estate properties. Hence, a majority of the investment should be from real estate or real estate like assets. The single regression model was used to determine the impact of book-to-market value alone on REITs share return (Model 2 in Table 6). This model showed the negative relationship between the book-to-market value and share return with strong significant less than 0.001 (model 2 in Table 7) in robust estimation against serial correlation and heteroskedasticity. Second, in the FVM indicate a negative relationship between book-to-market value and S-REITs return. The book-to-market values have a negative relationship with the S-REIT returns when selected macro and firm variables are included in the model (Table 10), which is in line with single regression and firm variable model. Overall, a negative effect between the book-to-market value in S-REITs was observed in this study failed to provide support to our initial hypothesis of a positive relationship between the book-to-market ratio and S-REIT return. Our finding does lend support to Chen et al., 1998 findings of a negative relationship between book-to-market and REIT returns.

For an analyst and an investor, the debt-to-equity ratio measures the leverage of the firm and exposes it to additional risk. This information helps to measure the percentage of assets funded by debt. REITs are exposed to high leverage, and $90 \%$ of the dividends have to be distributed in the form of dividends to shareholders. The single regression model interprets the debt-to-equity ratios as a distress factor. However, robust estimations against heteroskedasticity did not show significance at 0.05 (model 3 in Table 7). This model has a low explanatory power to estimate the variance of Singapore REITs stock return with R-square less than 5\% with significant F-ratio (model 3 in Table 6). The results of the firm variable model shown in model 5 in Table 6 estimated the relationship between the selected firm variables and share return. FVM models estimated the negative correlation with coefficient -0.06 between debt-to-equity ratio and the stock return of S-REITs, which in line with the single regression model. Like the single regression model, the robust estimation against serial correlation, heteroscedasticity's (model 5 in Table 7) loses its explanatory power with a p-value at 0.47 . However, the R-square that explains the variations in the S-REITs share return was only $15 \%$. The combined model shows a positive correlation between debt-to-equity and S-REITs (Table 10). However, none of the models showed significant results to explain the relation between debt-to-equity ratio and S-REITs share return. Thus, the a priori hypothesis that the debt-to-equity ratio would have a negative impact on S-REIT returns is not empirically supported, and the results leave us with an ambiguous finding.

In the early 1930s, before it is compulsory for firms to disclose the financials of a company, dividend distribution was a significant variable to measure financial health. As a shareholder, the dividend yield ratio measures the return on every dollar of investment. Single regression estimation (Model 4 in Table 6) of dividend yield showed a negative effect on returns in Singapore REITs with strong significant with p-value a 0.03 (Model- 4 in Table 7). This result showed R-square that explains the variations of share return is 3.6\% significant F-ratio (16.25). The $\mathrm{r}$-squared value was improved to $15 \%$ in the firm variable model when compared to the single regression model. The third model, which includes both firm and macroeconomic variables showed a negative relationship with the S-RETIS share return (Table 9). However, the robust against serial correlation and heteroskedasticity results showed the relationship between dividend yield and S-REITs was not significant at 95\%. R-square in the combined model has improved to $51 \%$ with significant F-statistic and indicated this model explains $51 \%$ of the variations in share return. The dividend yield has a negative impact on share returns in a combined model, which is contradictory with Fama and French (1988) study on dividend yields and expected stock returns. Sah and Zhou (2012) found the abnormal increase in the REITs returns immediately after the dividend announcements. Thus, the empirical findings in the S-REIT market fail to lend support to the hypothesis that higher dividend yields lead to higher REIT returns. This may be explained by the clientele effect, in which investors in the Singapore equity may not value dividends as investors in other market do.

\subsubsection{Macroeconomic Factor Results}

Table 8 displays the result of the most efficient panel model estimated based on the given equation. Both single regression and macroeconomic variable models are in favor of the pooled OLS model. Single regression model estimates with single explanatory variable results positive relationship between GDP and share return (model 1 in Table 8). The robust estimation showed strong explanatory power with a p-value at 0.003 (model 1 in Table 8), however R-square that explains the variance of the S-REITs share return is only $1.5 \%$ with significant F-statistic 8.9 when firm variables were included in the model, GDP showed a negative. The negative relationship between GDP and stock returns in FVM and the combined model is not consistent with findings from (Beck and Levine 2004), 
which showed that stock markets are positively related to economic growth. Thus, the alternative hypothesis predicting that that GDP has a positive correlation with share return is rejected

Table 8. Macro Economic Regression results

\begin{tabular}{|c|c|c|c|c|c|c|}
\hline & Model-1 ${ }^{(a)}$ & Model-2 $2^{(a)}$ & Model-3 ${ }^{(a)}$ & Model-4 ${ }^{(\text {a) }}$ & Model-5 $5^{(a)}$ & Model-6 ${ }^{(a)}$ \\
\hline Intercept & $\begin{array}{l}0.00083839 \\
(0.0811) \\
{[0.935395]}\end{array}$ & $\begin{array}{l}0.0214171 \\
(1.2485) \\
{[0.2124]}\end{array}$ & $\begin{array}{l}0.1442244 \\
(14.280) \\
{[<2.2 \mathrm{e}-16]^{* * *}}\end{array}$ & $\begin{array}{l}0.054658 \\
(0.6960) \\
{[0.4867]}\end{array}$ & $\begin{array}{l}-2.4365 \mathrm{e}-02 \\
(-1.0625) \\
{[0.28847]}\end{array}$ & $\begin{array}{l}1.3187 \mathrm{e}+00 \\
(4.6101) \\
{[4.9 \mathrm{e}-06]^{* * *}}\end{array}$ \\
\hline GDPN & $\begin{array}{l}0.31002301 \\
(2.9809) \\
{[0.00299]^{* *}}\end{array}$ & & & & & $\begin{array}{l}-4.8626 \mathrm{e}-02 \\
(-0.4870) \\
{[0.6264664]}\end{array}$ \\
\hline TERM & & $\begin{array}{l}0.0010262 \\
(0.0989) \\
{[0.9213]}\end{array}$ & & & & $\begin{array}{l}-1.5378 \mathrm{e}-02 \\
(-1.6663) \\
{[0.09622] .}\end{array}$ \\
\hline INF & & & $\begin{array}{l}-0.054115 \\
(-15.092) \\
{[<2.2 \mathrm{e}-16] * * *}\end{array}$ & & & $\begin{array}{l}-6.5265 \mathrm{e}-02 \\
(-14.0365) \\
{[<2.2 \mathrm{e}-16]^{* * *}}\end{array}$ \\
\hline $\mathrm{EX}$ & & & & $\begin{array}{l}-0.022872 \\
(-0.4055) \\
{[0.6853]}\end{array}$ & & $\begin{array}{l}-6.5552 \mathrm{e}-01 \\
(-4.2227) \\
{[2.819 \mathrm{e}-05]^{* * *}}\end{array}$ \\
\hline MS & & & & & $\begin{array}{l}4.9076 \mathrm{e}-07 \\
(2.1742) \\
{[0.03011]^{*}}\end{array}$ & $\begin{array}{l}-2.2338 \mathrm{e}-06 \\
(-3.5326) \\
{[0.0004458]^{* * *}}\end{array}$ \\
\hline R - Squared & 0.015619 & $1.7452 \mathrm{e}-05$ & 0.28914 & 0.000294 & 0.0083706 & 0.31377 \\
\hline $\begin{array}{l}\text { Adjst - R } \\
\text { Squared }\end{array}$ & 0.015564 & $1.739 \mathrm{e}-05$ & 0.28812 & 0.00029 & 0.0083408 & 0.31042 \\
\hline F-Statistic & $8.88553 * *$ & 0.0097 & $227.783 * * *$ & 0.164399 & $4.72709 *$ & $50.8439 * * *$ \\
\hline $\begin{array}{l}\text { Tests to compare } \\
\text { (BP-LM test) }\end{array}$ & ool/Fixed/Randor & odels & - & & - & - \\
\hline F- test & $\begin{array}{l}0.2738 \\
{[0.9997]}\end{array}$ & $\begin{array}{l}0.2704 \\
{[0.9997]}\end{array}$ & $\begin{array}{l}0.4791 \\
{[0.9796]}\end{array}$ & $\begin{array}{l}0.2721 \\
{[0.9997]}\end{array}$ & $\begin{array}{l}0.3172 \\
{[0.9989]}\end{array}$ & $\begin{array}{l}0.5037 \\
{[0.9722]}\end{array}$ \\
\hline Hausman Test & - & - & - & & - & - \\
\hline $\begin{array}{l}\text { Serial Correlation } \\
\text { Serial } \\
\text { Correlation } \\
\text { test(ChiSquare) }\end{array}$ & $\begin{array}{l}\text { \& heteroskedastic } \\
35.8657 \\
{[7.685 \mathrm{e}-06] * * *}\end{array}$ & $\begin{array}{l}\text { Test } \\
38.3895 \\
{[2.555 \mathrm{e}-06]^{* * *}}\end{array}$ & $\begin{array}{l}20.6392 \\
{[0.004343]^{* *}}\end{array}$ & $\begin{array}{l}37.7477 \\
{[3.384 \mathrm{e}-06]^{* *}} \\
*\end{array}$ & $\begin{array}{l}38.3876 \\
{[2.557 \mathrm{e}-06]^{* * *}}\end{array}$ & $\begin{array}{l}22.6699 \\
{[0.0019]^{* * *}}\end{array}$ \\
\hline $\begin{array}{l}\text { Heteroskedasticit } \\
\text { y test (B-P } \\
\text { Value) }\end{array}$ & $\begin{array}{l}52.3726 \\
{[4.591 \mathrm{e}-13]}\end{array}$ & $\begin{array}{l}6.2146 \\
{[0.01267]^{* *}}\end{array}$ & $\begin{array}{l}8.9091 \\
{[0.00284]^{* * *}}\end{array}$ & $\begin{array}{l}16.9295 \\
{[3.879 \mathrm{e}-05]^{* *}} \\
*\end{array}$ & $\begin{array}{l}18.7829 \\
{[1.465 \mathrm{e}-05]}\end{array}$ & $\begin{array}{c}97.1381 \\
{[<2.2 \mathrm{e}-16]}\end{array}$ \\
\hline
\end{tabular}

Note: See table 4 for variable description. Table 6 provides a description of the statistical tests.

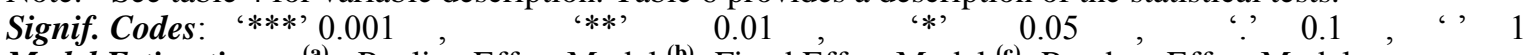

Model Estimation :- ${ }^{\left({ }^{(a)}\right.}$ - Pooling Effect Model ${ }^{\left({ }^{(b)}\right.}$ - Fixed Effect Model ${ }^{\left({ }^{(c)}\right.}$ - Random Effect Model

Value in closed brackets are t-statistics and in Squared brackets are P-Value

In a firm, term structure measures the cost of debt as they borrow to fulfill the needs of both short and long-term needs of the company. REITs consist of highly levered companies, and any changes in the interest rates will impact 
the REITs stock market. The single regression models result in a positive relationship between term structure and S-RETIS share return (model 2 in Table 8), and the robust estimation showed the positive correlation was not significant at 95\% (model 2 in Table 9). The second macroeconomic variable estimation (model 6 in Table 8) interpreted the term structure as a distress factor with stock returns in Singapore REITs. However, the robust results did not show significance at 95\% (model-6 in Table 9). Meanwhile, R-square has improved significantly from less than $1 \%$ to $31.3 \%$ in MVM model (Table 8). The term structure showed a negative correlation on the macroeconomic model and showed a positive correlation when firm variables were included in the model. However, none of the models show a significant correlation between term structure and S-REITs share return. Payne (2003) study found a negative correlation between term structure and share return in REITs, which is in line with the macroeconomic model but contradictory to the results of the combined model. These results contradict with macroeconomic variables defined by Chen et al. (1986), which showed a strong link with the interest rates. Hence, test results reject the alternative hypothesis that term structure is negatively correlated with S-REITs share return.

The estimation of the inflation rate in single regression models showed a negative effect on the share return (model 3 in Table 8) with strong explanatory power (Table 9) in robust estimation results. The inflation rate has a negative correlation with S-REITs share return in the macroeconomic variable model (model 6 in Table 8) with strong explanatory power with significant value at $95 \%$, and results are consistent with the single regression model. The $\mathrm{R}$-square in the macroeconomic model had increased from $29 \%$ to $31.3 \%$. When the firm variables were included with macroeconomic variables in the combined model, there is a negative correlation between inflation rate and S-REITs share return, while the robust estimation against serial correlation and heteroskedasticity showed strong significance with a p-value less 0.001(Table 10). The overall empirical findings support the hypothesis that S-REITs are negatively impacted by positive changes in the inflation rate, supporting the general literature on equity and REIT returns.

Table 9. Robust Estimation results

\begin{tabular}{|c|c|c|c|c|c|c|}
\hline & Model-1 $^{(a)}$ & Model-2 $2^{(a)}$ & Model-3 $3^{(\mathrm{c})}$ & Model-4 ${ }^{\text {(a) }}$ & Model-5 ${ }^{\text {(a) }}$ & Model-6 ${ }^{(a)}$ \\
\hline Intercept & $\begin{array}{l}0.000838 \\
(0.1127) \\
{[0.91034]}\end{array}$ & $\begin{array}{l}0.0214171 \\
(1.9805) \\
{[0.04814]^{*}}\end{array}$ & $\begin{array}{l}0.1442244 \\
(13.770) \\
{[<2.2 \mathrm{e}-16]^{* * *}}\end{array}$ & $\begin{array}{l}0.054658 \\
(1.0792) \\
{[0.281]}\end{array}$ & $\begin{array}{l}-2.4365 e-02 \\
(-1.3167) \\
{[0.18847]}\end{array}$ & $\begin{array}{l}1.3187 \mathrm{e}+00 \\
(2.9328) \\
{[0.003498]^{* *}}\end{array}$ \\
\hline GDPN & $\begin{array}{l}0.31002301 \\
(3.7244) \\
{[0.00216]^{* *}}\end{array}$ & & & & & $\begin{array}{l}-4.8626 \mathrm{e}-02 \\
(-0.4119) \\
{[0.6805]}\end{array}$ \\
\hline TERM & & $\begin{array}{l}0.0010262 \\
(0.1531) \\
{[0.87835]}\end{array}$ & & & & $\begin{array}{l}-1.5378 \mathrm{e}-02 \\
(-1.9077) \\
{[0.056949] .}\end{array}$ \\
\hline $\mathrm{InF}$ & & & $\begin{array}{l}-0.054115 \\
(-14.336) \\
{[<2.2 \mathrm{e}-16] * * *}\end{array}$ & & & $\begin{array}{l}-6.5265 \mathrm{e}-02 \\
(-8.5290) \\
{[<2.2 \mathrm{e}-16]^{* * *}}\end{array}$ \\
\hline EX & & & & $\begin{array}{l}-0.022872 \\
(-0.6072) \\
{[0.544]}\end{array}$ & & $\begin{array}{l}-6.5552 \mathrm{e}-01 \\
(-2.7288) \\
{[0.0066]^{* *}}\end{array}$ \\
\hline MS & & & & & $\begin{array}{l}4.9076 \mathrm{e}-07 \\
(2.9585) \\
{[0.00322]^{*}}\end{array}$ & $\begin{array}{l}-2.2338 \mathrm{e}-06 \\
(-2.3633) \\
{[0.0184]^{*}}\end{array}$ \\
\hline
\end{tabular}

\footnotetext{
Note: See table 4 for variable description. Table 6 provides a description of the statistical tests.

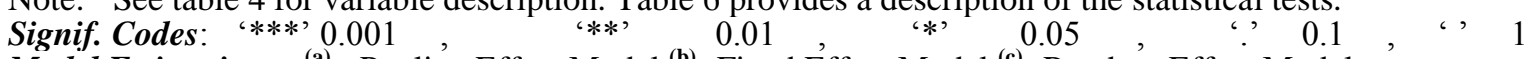
Model Estimation :- ${ }^{(a)}$ - Pooling Effect Model ${ }^{(b)}$ - Fixed Effect Model ${ }^{(\mathbf{c})}$ - Random Effect Model Value in closed brackets are t-statistics and in Squared brackets are P-Value
} 
Table 10. Firm and Macro Regression results

\begin{tabular}{|c|c|c|}
\hline & Model-1 ${ }^{(\mathrm{b})}$ & $\begin{array}{l}\text { Robust } \\
\text { Results }^{(b)}\end{array}$ \\
\hline \multicolumn{3}{|l|}{ Intercept } \\
\hline EPS & $\begin{array}{l}-6.7518 \mathrm{e}-02 \\
(-0.9356) \\
{[0.350052]}\end{array}$ & $\begin{array}{l}-6.7518 \mathrm{e}-02 \\
(-1.5737) \\
{[0.116349]}\end{array}$ \\
\hline BTM & $\begin{array}{l}-1.0003 \mathrm{e}-01 \\
(-4.427) \\
{[1.23 \mathrm{e}-05]^{* * *}}\end{array}$ & $\begin{array}{l}-1.0003 \mathrm{e}-01 \\
(-2.346) \\
{[0.019428]^{* * *}}\end{array}$ \\
\hline $\mathrm{DE}$ & $\begin{array}{l}7.7710 \mathrm{e}-02 \\
(1.5547) \\
{[0.120793]}\end{array}$ & $\begin{array}{l}7.7710 \mathrm{e}-02 \\
(1.0166) \\
{[0.309]}\end{array}$ \\
\hline DY & $\begin{array}{l}-7.9526 \mathrm{e}-03 \\
(-2.3956) \\
{[0.017047]^{*}}\end{array}$ & $\begin{array}{l}-7.9526 \mathrm{e}-03 \\
(-0.8977) \\
{[0.369876]^{*}}\end{array}$ \\
\hline GDPN & $\begin{array}{l}8.6806 \mathrm{e}-01 \\
(-7.0600) \\
{[7.31 \mathrm{e}-12]^{* * *}}\end{array}$ & $\begin{array}{l}8.6806 \mathrm{e}-01 \\
(-6.3858) \\
{[4.691 \mathrm{e}-10]^{* * *}}\end{array}$ \\
\hline TERM & $\begin{array}{l}2.4200 \mathrm{e}-02 \\
(2.1020) \\
{[0.036168]^{*}}\end{array}$ & $\begin{array}{l}2.4200 \mathrm{e}-02 \\
(1.9379) \\
{[0.053335] .}\end{array}$ \\
\hline InF & $\begin{array}{l}6.9723 \mathrm{e}-02 \\
(-14.1523) \\
{[<2.2 \mathrm{e}-16]^{* * *}}\end{array}$ & $\begin{array}{l}6.9723 \mathrm{e}-02 \\
(-12.1605) \\
{[<2.2 \mathrm{e}-16]^{* * *}}\end{array}$ \\
\hline EX & $\begin{array}{l}-4.6427 e-01 \\
(-2.3702) \\
{[0.018248]^{*}}\end{array}$ & $\begin{array}{l}-4.6427 \mathrm{e}-01 \\
(-2.1131) \\
{[0.035207]^{*}}\end{array}$ \\
\hline MS & $\begin{array}{l}-2.4420 \mathrm{e}-06 \\
(-3.4693) \\
{[0.000578]^{* * *}}\end{array}$ & $\begin{array}{l}-2.4420 \mathrm{e}-06 \\
(-3.26) \\
{[0.001184]^{* *}}\end{array}$ \\
\hline $\begin{array}{l}\text { R - Squared } \\
\text { Adjst - R Squared } \\
\text { F-Statistic }\end{array}$ & $\begin{array}{l}0.51056 \\
0.47417 \\
46.8257 * * *\end{array}$ & \\
\hline $\begin{array}{l}\text { Tests to compare Pool/F } \\
\text { (BP-LM test) }\end{array}$ & $\begin{array}{l}\text { ls } \\
93.8785 \\
{[<2.2 \mathrm{e}-16]^{* * *}}\end{array}$ & \\
\hline F- test & $\begin{array}{l}1.6335 \\
{[0.03911]^{*}}\end{array}$ & \\
\hline Hausman Test & $\begin{array}{l}62.0054 \\
{[5.497 \mathrm{e}-10]^{* * *}}\end{array}$ & \\
\hline Published by Sciedu Press & 38 & E-ISSN 1927-5994 \\
\hline
\end{tabular}


Serial Correlation \& Heteroskedasticity Test

Serial Correlation test (ChiSquare)

Heteroskedasticity test (B-P Value) $\quad 73.5754$

[3.018e-12]

Note: See table 4 for variable description. Table 6 provides a description of the statistical tests.

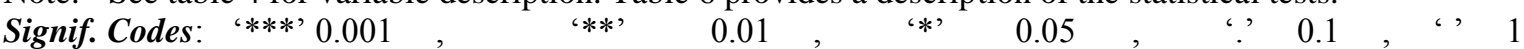

Model Estimation :- ${ }^{(\mathbf{a})}$ - Pooling Effect Model ${ }^{\left({ }^{b}\right)}$ - Fixed Effect Model ${ }^{(\mathrm{c})}$ - Random Effect Model

Value in closed brackets are $t$-statistics and in Squared brackets are P-Value

Foreign investments are a major source of income for Singapore. Many investors also seek diversification in Asian real estate markets. Therefore, the exchange rate between Singapore and the US dollar was considered to observe the reaction of stock returns in 23 Singapore REITs firms using the panel regression techniques. The estimation of the exchange rate showed a negative reaction with the stock return in sole estimation model (model 4 in Table 8). However, robust estimation results did not show any significance (model 4 in Table 9). R-square estimated for this model was less than 1\%, and the F-statistic is not significant (model 4 in Table 8).

Money supply (M1) was used to observe the reaction of money supply on Singapore REITs stock return while panel regression analysis was undertaken to study the cross section and time series data. The results of the single regression model estimated using the pooled OLS techniques shown in model 5 (Table 8). This estimation shows the positive correlation between money supply and Singapore REITs stock return with significant explanatory power in robust estimation against serial correlation and heteroskedasticity (model 5 in table 9). The R-square in this regression was less than $1 \%$ with significant F-ratio of 4.7 (model 5 in Table 8). Following the rule of thumb, this study considers the single regression model as inefficient due to the low R-square that explains the variations of S-REITs Share return.

Based on the findings, two possible explanations can be derived. First, a positive correlation was observed in the single regression model, but, the MVM model and combined models showed a negative correlation between money supply and share return with strong significance. The R-square estimated in the combined model was $51 \%$, and this model is considered more robust. Hence, the alternative hypothesis that predicts that the money supply has a positive correlation with REITs stock return is rejected. These results are contradictory with results from a previous study predict a strong significant positive correlation between the supply of money and REITs share return (Al-Shubiri 2010; Ngo 2017).

Our overall findings have determined the relationship between the macroeconomic variables and REITs share return has R-square of 31.3\% (model 6 in Table 8); whereas, all of the single regression models showed the R-square of less than 5\%. When firm variables were included in the model, the R-square has increased from $31.3 \%$ to $51 \%$ (Table 10). GDP, inflation rate (INF), money supply (M1) and exchange rate, show a significant relationship with REITs return in the macroeconomic variable model. Thus, the findings are in line with the arbitrage pricing theory as defined by (Ross 1976; Payne 2003)) which stipulated that macroeconomic variables have strong explanatory power with share returns. Term structure showed a negative correlation with share return in the single regression model and positive correlation in MVM and combined model.

\section{Conclusion}

This paper investigates the determinants of stock returns in S-REITs for the period of 2004 to 2013, using simple panel regression models. Previous studies showed that fundamental factors impact the stock market (De Bondt 2008), while a study by Chen et al. (1986) found that macroeconomic variables play a significant role in excess stock returns. Thus, this study utilized both firm variables, namely earnings per share, book-to-market value, dividend yield, and debt-to equity-ratio, and macroeconomic variables like GDP, money supply, inflation rate, term structure and exchange rate to observe the reaction returns in Singapore REITs.

None of the firm variables, except for book-to-market value, have a significant impact on REIT returns in Singapore. The negative effect of the book-to-marker ratio supports the findings Chen et al. (1998). However, this contradicts the other studies that showed a positive relation between book-to-market value and returns in non-REITs firms. Macroeconomic variables like GDP, inflation rate, money supply, and exchange rate were shown to have a significant impact with Singapore REIT returns. For example, the inflation rate shows a strong significant negative impact. Evidence is found that an increase in the exchange rate between Singapore and US currency may decrease the REITs stock prices. 
Overall, S-REIT returns are influenced primarily through macroeconomic factor and the determinants of their returns are fairly unique when compared to other REIT markets. This suggests that global investors may diversity their portfolios of real estate with S-REITs to provide returns that are not significantly influenced by firm-specific factors. Additionally, this research provides evidence to support the notion that analysts and investors should allocate most of their resources to identify macroeconomic shocks or changes when investing in S-REITs as compared to REIT specific factors. Further studies can extend the research on S-REITs to include an analysis on a REIT sector specific basis (e.g., residential REIT, commercial REIT, etc.).

\section{References}

Al-Shubiri, F. N. (2010). Analysis the determinants of market stock price movements: An empirical study of Jordanian commercial banks. International Journal of Business and Management, 5, 137-146. https://doi.org/10.5539/ijbm.v5n10p137

Ang, A., Nabar, N., \& Wald, S. J. (2013). Searching for a common factor in public and private real estate returns. The Journal of Portfolio Management, 39, 120-133. https://doi.org/10.3905/jpm.2013.39.5.120

Basse, T., Friedrich, M., \& Bea, E. V. (2009). REITs and the financial crisis: Empirical evidence from the US. International Journal of Business and Management, 4, 3. https://doi.org/10.5539/ijbm.v4n11p3

Beck, T., \& Levine, R. (2004). Stock markets, banks, and growth: Panel evidence. Journal of Banking \& Finance, 28, 423-442. https://doi.org/10.1016/S0378-4266(02)00408-9

Bhandari, L. C. (1988). Debt/equity ratio and expected common stock returns: Empirical evidence. The Journal of Finance, 43, 507-528. https://doi.org/10.1111/j.1540-6261.1988.tb03952.x

Brounen, D., \& de Koning, S. (2013). 50 Years of Real Estate Investment Trusts: An International Examination of the Rise and Performance of REITs. Journal of Real Estate Literature, 20, 197-223.

Brown, S. L. (1978). Earnings changes, stock prices, and market efficiency. The journal of finance, 33, 17-28. https://doi.org/10.1111/j.1540-6261.1978.tb03386.x

Chang, H.-L., Chen, Y.-S., Su, C.-W., \& Chang, Y.-W. (2008). The relationship between stock price and EPS: Evidence based on Taiwan panel data. Economics Bulletin, 3, 1-12.

Chang, K.-L., Chen, N.-K., \& Leung, C. K. Y. (2011). Monetary policy, term structure and asset return: comparing REIT, housing and stock. The Journal of Real Estate Finance and Economics, 43, 221-257. https://doi.org/10.1007/s11146-010-9241-8

Chen, N.-F., Roll, R., \& Ross, S. A. (1986). Economic forces and the stock market. Journal of Business, 21, 383-403. https://doi.org/10.1086/296344

Chen, S.-J., Hsieh, C., Vines, T., \& Chiou, S.-N. (1998). Macroeconomic variables, firm-specific variables and returns to REITs. Journal of Real Estate Research, 16, 269-278.

Chui, A. C., Titman, S., \& Wei, K. J. (2003). The cross section of expected REIT returns. Real Estate Economics, 31, 451-479. https://doi.org/10.1111/1540-6229.00073

Clayton, J., \& MacKinnon, G. (2003). The relative importance of stock, bond and real estate factors in explaining REIT returns. The Journal of Real Estate Finance and Economics, 27, 39-60. https://doi.org/10.1023/A:1023607412927

Croissant, Y., \& Millo, G. (2008). Panel data econometrics in R: The plm package. Journal of Statistical Software, 27, 1-43. https://doi.org/10.18637/jss.v027.i02

De Bondt, G. J. (2008). Determinants of stock prices: New international evidence. The Journal of Portfolio Management, 34, 81-92. https://doi.org/10.3905/jpm.2008.706246

Elliott, G., \& Timmermann, A. (2013). Handbook of economic forecasting: Elsevier.

Fama, E. F., \& French, K. R. (1988). Dividend yields and expected stock returns. Journal of Financial Economics, 22, 3-25. https://doi.org/10.1016/0304-405X(88)90020-7

Fama, E. F., \& Schwert, G. W. (1977). Asset returns and inflation. Journal of Financial Economics, 5(2), 115-146. https://doi.org/10.1016/0304-405X(77)90014-9 
Fei, P., Ding, L., \& Deng, Y. (2010). Correlation and volatility dynamics in REIT returns: performance and portfolio

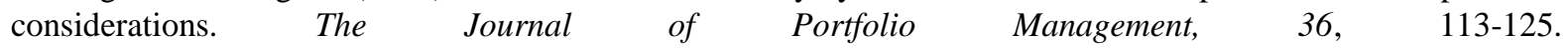
https://doi.org/10.3905/JPM.2010.36.2.113

Foo Sing, T., Hiang Liow, K., \& Chan, W.-J. (2002). Mean reversion of Singapore property stock prices towards their fundamental values. Journal of Property Investment \& Finance, 20, 374-387. https://doi.org/10.1108/14635780210435056

Granger, C. W., Huangb, B.-N., \& Yang, C.-W. (2000). A bivariate causality between stock prices and exchange rates: evidence from recent Asianflu. The Quarterly Review of Economics and Finance, 40, 337-354. https://doi.org/10.1016/S1062-9769(00)00042-9

Han, J., \& Liang, Y. (2009). The historical performance of real estate investment trusts. Journal of Real Estate Research, 10, 235-262

Hardin III, W., \& Hill, M. D. (2008). REIT dividend determinants: excess dividends and capital markets. Real Estate Economics, 36, 349-369. https://doi.org/10.1111/j.1540-6229.2008.00216.x

Kim, D. (1997). A reexamination of firm size, book-to-market, and earnings price in the cross-section of expected stock returns. Journal of Financial and Quantitative Analysis, 32, 463-489. https://doi.org/10.2307/2331233

Li, J., \& Lei, L. (2011). Determinants and information of REIT pricing. Applied Economics Letters, 18, 1501-1505. https://doi.org/10.1080/13504851.2010.543074

Ling, D. C., \& Naranjo, A. (2015). Returns and information transmission dynamics in public and private real estate markets. Real Estate Economics, 43, 163-208. https://doi.org/10.1111/1540-6229.12069

Liow, K. H., \& Li, Y. (2006). Net asset value discounts for Asian-Pacific real estate companies: long-run relationships and short-term dynamics. The Journal of Real Estate Finance and Economics, 33, 363-388. https://doi.org/10.1007/s11146-006-0338-z

Liu, C. H., \& Mei, J. (1998). The predictability of international real estate markets, exchange rate risks and diversification consequences. Real Estate Economics, 26, 3-39. https://doi.org/10.1111/1540-6229.00736

Lizieri, C., Satchell, S., \& Worzala, E. (2009). Real interest regimes and real estate performance: a comparison of UK and US markets. Journal of Real Estate Research, 16, 339-356.

Lu, C., \& So, R. W. (2001). The relationship between REITs returns and inflation: a vector error correction approach. Review of Quantitative Finance and Accounting, 16, 103-115. https://doi.org/10.1023/A:1011225723400

Nelling, E., \& Gyourko, J. (2009). The predictability of equity REIT returns. Journal of Real Estate Research.

Ngo, T. (2017). Exchange rate exposure of REITs. The Quarterly Review of Economics and Finance, 64, 249-258, https://doi.org/10.1016/j.qref.2016.09.002

Payne, J. E. (2003). Shocks to macroeconomic state variables and the risk premium of REITs. Applied Economics Letters, 10, 671-677. https://doi.org/10.1080/1350485032000133345

Peterson, J. D., \& Hsieh, C. H. (1997). Do common risk factors in the returns on stocks and bonds explain returns on REITs?. Real Estate Economics, 25, 321-345. https://doi.org/10.1111/1540-6229.00717

Quan, D. C., \& Titman, S. (1999). Do real estate prices and stock prices move together? An international analysis. Real Estate Economics, 27, 183-207. https://doi.org/10.1111/1540-6229.00771

Rjoub, H., Türsoy, T., \& Günsel, N. (2009). The effects of macroeconomic factors on stock returns: Istanbul Stock Market. Studies in Economics and Finance, 26, 36-45. https://doi.org/10.1108/10867370910946315

Rogalski, R. J., \& Vinso, J. D. (1977). Stock returns, money supply and the direction of causality. The Journal of Finance, 32, 1017-1030. https://doi.org/10.1111/j.1540-6261.1977.tb03306.x

Ross, S. A. (1976). The arbitrage theory of capital asset pricing. Journal of Economic Theory, 13, 341-360. https://doi.org/10.1016/0022-0531(76)90046-6

Saeidi, P., \& Khandoozi, B. (2011). The investigation of relation between market ratios and market price per share of accepted companies in Tehran stock exchange. Global Business and Management Research: An International Journal, 3, 136-140. 
Sah, V., \& Zhou, X. (2012). Elective stock dividend in REITs: market reaction and determinants. Journal of Property Investment \& Finance, 30, 583-595. https://doi.org/10.1108/14635781211264531

Spiess, D. K., \& Affleck-Graves, J. (1999). The long-run performance of stock returns following debt offerings. Journal of Financial Economics, 54, 45-73. https://doi.org/10.1016/S0304-405X(99)00031-8

Su, H.-M., Huang, C.-M., \& Pai, T.-Y. (2010). The hybrid characteristic of REIT returns: evidence from Japanese and US States markets. Journal of Real Estate Literature, 18, 77-98.

Titman, S., \& Warga, A. (1986). Risk and the performance of real estate investment trusts: A multiple index approach. Real Estate Economics, 14, 414-431. https://doi.org/10.1111/1540-6229.00395

Yung, K., Li, D. D., \& Jian, Y. (2017). Managerial decision horizon and real estate investment trusts (REITs). Review of Behavioral Finance, 9, 63-78. https://doi.org/10.1108/RBF-06-2015-0026

Zietz, E., Sirmans, S., \& Friday, S. (2003). The environment and performance of real estate investment trusts. Journal of Real Estate Portfolio Management, 9, 127-165. 